\title{
CAPITAL PUNISHMENT
}

\author{
L. T. PENNELL*
}

The question of the abolition of capital punishment has had an extensive airing in the Parliaments of both Canada and the United Kingdom during recent years. In the most recent debate in the Canadian House of Commons, the member for Leeds, Mr. John Matheson, suggested that this renewed interest in the subject is attributable to the fact that "we belong to the caring generation". Whatever the merits of this statement, it is clear that across a wider spectrum of our community than has ever before been the case, capital punishment is now considered to be a moral and political issue of the first magnitude.

At the same time, it cannot be said the extensive debate to this date has resulted in any consensus. In the United Kingdom, capital punishment was abolished for a five-year period by a bill adopted by Parliament during the summer and autumn of 1965, and given Royal Assent on November 8, of that year. That there is still a good deal of sentiment of favour of the death penalty in that country, however, is illustrated by the recent furore there surrounding the shooting murder of three London police constables, which was followed by a debate in the Commons on Mr. Duncan Sandys' motion for reintroduction of the death penalty. The Sandys' motion was defeated but the heat of the debate indicated that the abolitionists have not yet completely carried the day.

In Canada, the House of Commons devoted a full five days to the subject in March of last year. By any standard of measurement of Parliamentary debates, this was an excellent one. Speeches were lucid, delivered with great sincerity on all sides, and extremely well researched. At the conclusion of the debate, three separate motions were put to the House, each of which would have abolished capital punishment to some degree. In each case, the motion was defeated.

Because of the manner in which the motions were worded, however, it remains unclear what were the sentiments which the House actually put on the record. On the one hand, it could be argued, I suppose, that the votes were in fact a resounding defeat for the abolitionist cause. On the other hand, it could be argued, with equal respectability, that the House really showed itself to be almost evenly divided on the question of some form of abolition.

If nothing else, the recent Parliamentary history indicates that the movement towards greater leniency in our criminal law, which began centuries ago with the abolition of the rack and the wheel, is a slow and tortured process.

Perhaps it would be useful if I were to set out this recent Parliamentary history in greater detail.

One of the most significant occurrences in this area in the post-WorldWar-II period was the report of the U.K. Royal Commission on Capital

- The Honourable L. T. Pennell, Q.C., Solicitor-General of Canada. 
Punishment. This Royal Commission, under the chairmanship of Sir Ernest Gowers, carried out its studies over the four-year period from 1949 to 1953 . Its terms of reference were not to bring in a recommendation either for or against the abolition of capital punishment, but rather to consider whether there should be amendments to the statutory definition of capital murder; to make recommendations as to the proper term of imprisonment for persons guilty of some lesser form of culpable homicide; and to consider the problem of imprisonment of such persons in its wider aspects.

Sir Ernest Gowers has since been reported as having said that he began his work disposed, if anything, towards retention of the death penalty as an effective deterrent to murder. After four years of careful consideration of the problem, he was able to suggest in his final report that he agreed with the American sociologist Thorsten Sellin that it was absolutely impossible to demonstrate, on any reliable statistical basis, that the death penalty serves in any way as a deterrent to the commission of homicides. "It is accordingly important" the Report concluded, "to view the question in a just perspective and not to base a penal policy in relation to murder on exaggerated estimates of the uniquely deterrent force of the death penalty". 1

It is interesting to note in passing that the Royal Commission also concluded that it was impractical to attempt to draw up a criminal statute which would segregate murder into various shades of culpability. The Royal Commission therefore put the issue squarely before Parliament on this basis: Parliament, it said in effect, had to make up its mind either for or against abolition. The matter could not effectively be settled, it said, by attempting to distinguish "capital" from "non-capital" murder. This advice was later ignored by the U.K. government, which introduced "non-capital" murder concepts into the law of the land in 1957. A similar step was taken in Canada in $1961 .^{2}$

Although the Report of the Royal Commission has been a valuable instrument in the hands of abolitionists in the U.K. since 1953, it should not be forgotten that there were a considerable number of abolitionists in Parliament even before that date.

Indeed, one of the reasons for the appointment of the Commission was the unusual occurrence in the House of Commons of April 14, 1948, when Mr. Sidney Silverman's amendment (to the Criminal Justice Bill which was then before the House), proposing abolition for an experimental five-year period, was carried 245-222 over the protests of the Home Secretary. The Labour government was later rescued from this position of having policy thrust upon it by the Commons when the House of Lords refused to pass the Bill as amended.

At this late stage, the Labour government attempted a compromise, and introduced a bill which would have reserved the death penalty only for the most heinous crimes. The approval of the House of Commons was obtained easily, but once again the measure was defeated by the Lords.

1 United Kingdom Royal Commission on Capital Punishment Report, para. 68.

2 Criminal Code, S.C. 1960-61, c. 44, s.1. 
The matter was largely left in abeyance until 1956, although several private members attempted (unsuccessfully) during the interim to advance abolition bills to the debate stage.

The 1956 experience was largely a repetition of the 1949 one. On February 16, 1956, the Home Secretary introduced a motion calling for an amendment to the law of murder, while retaining the death penalty in some circumstances. The motion was defeated, the House choosing instead to adopt Mr. Chuter Ede's amending motion that legislation should be introduced abolishing capital punishment for five years. The Prime Minister then announced that the government would give expression to the resolution by advancing Mr. Sidney Silverman's private bill to the debate stage. When this was done, the bill carried; only to be rejected 283-95 in the House of Lords.

At this stage, the government of the day attempted another compromise, this time with success. The U.K. Homicide Act of 1957, providing for a distinction between "capital" and "non-capital" murders, secured the approval of both Houses.

In any event, the 1957 legislation remained the law of the United Kingdom until 1965, when the Murder (Abolition of Death Penalty) Act was passed, providing the five-year ban on executions which many members of the House of Commons had been seeking. I have already mentioned the recent unsuccessful assault on that legislation made by Mr. Duncan Sandys.

I have outlined this British legislative history at some length, to illustrate how difficult it is to secure public and parliamentary acceptance for abolition legislation. The question of the death penalty seems to be a problem which touches the social conscience at its very roots.

Despite this, there seems to be an increasing number of jurisdictions which have abolished the death penalty. Some forty countries no longer execute their murderers, and the list includes Austria, Argentina, Belgium, Brazil, Italy, West Germany, Israel, Norway, Sweden, Denmark, The Netherlands, Mexico, Portugal, Switzerland, Venezuela and New Zealand. The Australian state of Queensland, and the American states of Michigan, Wisconsin, Maine, Minnesota, Hawaii, and Alaska, are also on the list. In Rhode Island and North Dakota, I understand the death penalty is provided only for those who commit first degree murder while serving a sentence of imprisonment for a previous first degree murder.

The question of abolition was considered in detail in Canada by a joint committee of the Senate and House of Commons, which submitted its report to Parliament on June 27, 1956. In General, the report did not support in any way the cause of the abolitionists of the day. It recommended against any change in the definition of murder; suggested nothing could be gained by creating "degrees" of murder; and opted for retention of death as the mandatory penalty for murder and treason. At the same time, however, it suggested certain improvements in the appeal procedures applicable to murder convictions; said that murderers under 18 should not be hanged (a provision brought into Canadian law in 1961, several years after the conviction of Stephen Truscott, whose sentence had nevertheless been commuted by the Cabinet); and re- 
commended that the gallows be replaced by electrocution or the gas chamber as a means of execution.

In 1961, the government of the day amended the Criminal Code by instituting the "non-capital" murder provisions which are still in force. ${ }^{3}$ The effect of these, of course, was to confine the designation of "capital murder" to homicides carried out on the basis of a deliberate plan; to homicides of police officers and prison guards; and to a number of "felony murders", that is, homicides committed in the course of some felony such as robbery or rape. For "non-capital" murder, life imprisonment was provided as the mandatory penalty. We now stand at this halfway house and perhaps I might be permitted this marginal note. In my respectful opinion the division of capital and non-capital murders cannot be defended on grounds of logic. Certainly it does not divide crimes according to their moral culpability. Some less heinous acts are deemed capital murders while more heinous acts are sometimes held to be non-capital murders.

This 1961 legislation had been preceded by a two-day debate in February, 1960, on Mr. Frank Magee's private abolition bill. That debate had provided a forum for M.P.'s to air their views on the subject, but the motion for second reading of Mr. Magee's bill never came to a vote, and so the debate had fizzled out. Mr. Magee himself moved to withdraw his bill on August 10, 1960, his conferences with fellow-M.P.'s apparently having convinced him that there was no chance of pursuing the matter to a successful conclusion.

Finally, in April, 1966, the government made time available for the House to debate an abolition bill co-sponsored by four private members, representing the Liberal, Conservative, and New Democratic parties. It was announced that the whips would be called off, and that each member of the House could vote on the matter as his conscience dictated. The result, as I have indicated, was defeat of the bill, and defeat as well for two proposed amendments to it.

The manner in which the House voted on these various proposals is of some interest. To begin with, Mr. Donald MacDonald (Liberal, Rosedale), proposed an amendment to the abolition bill which would have had the result of giving the measure effect only "on a trial basis for a period of five years". This was defeated 138-113. The House next voted on an amendment proposed by Mr. Milton Klein (Liberal, Cartier), which would have abolished capital punishment except in cases of murders of prison guards or police officers. This was defeated 179-112. Finally, on the main motion for a total abolition of the death penalty, the vote was 143-112 against.

The absence of any floor leadership in the House while this voting was going on produced some confusion. In particular, many of those who strongly favoured total abolition voted against any watered-down formula, and allowed the two amendments to be defeated by unrealistically large votes. I have since calculated that if all those who favoured a regime of total abolition had voted for Mr. Milton Klein's amendment, that amendment would have been defeated only by a relatively narrow

3 Ibid. 
vote of 133-127. It is on this basis that I feel that the House showed itself at that time to be closely divided on the question of partial abolition.

My own position in all this was that I voted in favour of each amendment, and also in favour of the main proposal. I believe that the death penalty should be abolished, but I would have been willing to compromise to achieve at least a measure of abolition. Perhaps I should now say something about why I feel the death penalty is an anachronism which should be removed from our system of administration of justice.

In the space of a short article, I cannot hope to deal with each of the arguments put forward last year and in $\mathbf{1 9 6 0}$ by those who favoured retention. Many said they were convinced the death penalty served a deterrent effect. Others said that no less severe penalty could adequately express the community's sense of revulsion at murder. Some members spoke of the necessity of "amputating" the murderer from the community, in the manner that a surgeon amputates a gangrenous limb. Finally, some members suggested that the scriptures endorse the death penalty as a fitting reward for murder, and that any lesser punishment would run counter to Divine will.

My basic philosophical approach is simple enough, I think. I believe we should not take human life unless it is absolutely clear that some worthwhile purpose would be served by doing so. If we err in the administration of justice, it should be in the direction of preserving life, rather than towards taking it, even when the life being taken is that of a convicted murderer.

History has shown that every mitigation of penal severity has always produced loud protests and dark forecasts of disaster. But time and experience have destroyed the illusion that we can overcome violent crime by ourselves adopting violent methods.

The second half of my approach to the problem consists of this; that so far as I can tell it cannot be shown, in any objective way, that any useful purpose is really served when the community follows up a murder with a judicial execution.

On this question of deterrence, I am profoundly impressed by the findings of the statisticians, including in particular Professor Thorsten Sellin, that the experience of jurisdictions which have abolished the death penalty does not tend to show, statistically, that the execution of murders deters the commission of the crime.

\section{The Report of the Royal Commission on capital punishment said:}

We agree with Professor Sellin that the only conclusion which can be drawn from the figures is that there is no clear evidence of any influence of the death penalty on the homicide rates of these states and that whether the death penalty is used or not and whether executions are frequent or not both death penalty states and abolition states show rates which suggest that these rates are conditioned by factors other than the death penalty. ${ }^{*}$

Indeed, Professor Sellin went so far as to say before the 1956 Canadian Parliamentary Committee that the statistics actually point the other way, and indicate that more murders tend to be committed where the death penalty is in force. 
Of course, I appreciate that those who speak of deterrence do not have in mind only the statistics of the matter. There is a more subtle variation of the "deterrence" theme which was very well expressed in the words of the Royal Commission Report:

... the deterrent force of capital punishment operates not only by affecting the conscious thoughts of individuals tempted to commit murder, but also by building up in the community, over a long period of time, a deep feeling of peculiar abhorrence for the crime of murder. The fact that men are hung for murder is one great reason why murder is considered so dreadful a crime. This widely diffused effect on the moral consciousness of society is impossible to assess, but it must be at least as important as any direct part which the death penalty may play as a deterrent in the calculations of potential murderers. It is likely to be specially potent in this country, where the punishment for lesser offences is much more lenient than in many other countries, and the death penalty stands out in sharper contrast. ${ }^{5}$

There is also the view which was expressed by Lord Justice Denning as follows:

The ultimate justification of any punishment is not that it is a deterrent, but that it is an emphatic denunciation by the community of a crime: and from this point of view there are murders which, in the present state of public opinion, demand the most emphatic denunciation of all-namely the death penalty."

These are interesting approaches, but are they valid ones?

To begin with, they seem to assure that the type of person who commits murder would be affected by rather subtle ideas at large in the community about the sanctity of life. My own belief, based partly on practical experience in the criminal courts, is that the murderer does not usually care about subtleties of that kind. Murders are usually done as crimes of passion, or by persons who have lost the will to live themselves and express their hopelessness by ending other persons' lives, or by individuals whose contempt for the sanctity of life frequently verges on the psychopathic.

In my humble opinion, the "deterrence" arguments expressed above are in essence appeals to the old Lex Talionis, the law of an eye for an eye, a tooth for a tooth. Our penal system has a three-fold function. It seeks to punish the offender, tries to reform him and aims to deter others from repeating his offence. It is not concerned with exact retaliation or precise retribution, but it seems to me that this is the principle that is kept alive by the imposition of the death sentence. It is my submission that severity of punishment alone cannot lead to the maintenance of respect for the law. The question of the certainty of detection and conviction is an overriding factor. It is, I suggest, common sense that crime will continue to flourish if those who are committing crimes go unapprehended. The basic point, in my view, is the certainty of detection and conviction.

Apart from this, there are other considerations. One is that judicial execution is a very cold-blooded and horrifying act that cannot be justified unless it is established that it is absolutely necessary. If we want to instill respect for life among all members of our community, surely we do not do it by acts of this kind at the highest level of our system of justice. A much better alternative, I think, is to demonstrate in a practical way

5 Id., para. 20.

i Id., para. 53. 
that our system of justice abhors the taking of any life under any circumstances.

Then there is the horrifying fact that innocent men have been executed in the past, and may die in the future if the death penalty remains in force. The English author Arthur Koestler has documented a number of such cases in his book Reflections on Hanging. ${ }^{\top}$ In the recent past in England, we have had the murder case involving John Reginald Christie and Timothy Evans. Evans was executed for murdering his child, but Christie later confessed the crime and Evans has since been awarded a posthumous pardon.

In the words of Lord Birkett:

The case against Evans at his trial on the facts as they were then known was quite overwhelming. There was no failure in the administrative machinery of the criminal law. No human skill could have prevented the conviction, and no human judicial system, whatever its checks and safeguards, can ever provide complete security against the exceedingly rare and utterly exceptional case such as that of Evans. ${ }^{8}$

Whatever care is taken in the judicial process, the chance of mistakes is bound to arise. Do we have the moral right, being fallible and human to administer a punishment we cannot undo if subsequently the judgement is found to be wrong?

There is a final point which I should make. The interests of humanitarianism will not be served simply by commuting death sentences to sentences of life imprisonment, and then allowing the condemned man to languish indefinitely in a cell. There can be no question that there are some murderers who are so dangerous that it would be unsafe to let them ever go free, for the protection of society is paramount. But is it too much to suggest that with present developments in the scientific study of the human mind, society in the long run would receive more benefit from the study of the psychopath than it would benefit by hanging him?

Abolition, if it comes, should be accompanied also by efforts within our penitentiaries to achieve a rehabilitation of the murderer himself, with the object of eventually releasing him, after a period of appropriate length, to some sort of productive work in the community. Nathan Leopold's work in hospitals today is perhaps some compensation for "the crime of the century" which he committed many years ago in Chicago.

I hope that, in time, it will be possible for Canada to achieve all these goals. At that time, perhaps, we will be closer to that perfect justice which we all desire.

7 Gollancz, 1956, London.

8 The Observer, January 15, 1961. 